\title{
IMPACT OF SELECTED FACTORS ON THE CROSS-BORDER PRICE OF POSTAL PARCELS IN THE EUROPEAN UNION
}

\author{
MAREK SYLWESTRZAK, ${ }^{1}$ ANNA STOLARCZYK ${ }^{2}$
}

The National Institute of Telecommunications, POLAND

${ }^{1}$ e-mail: m.sylwestrzak@itl.waw.pl

2 e-mail: a.stolarczyk@itl.waw.pl

\begin{tabular}{l|l} 
RECEIVED & 5 August 2017 \\
ACCEPTED & 15 December 2017 \\
JEL & \\
CLASSIFICATION & L87, O31
\end{tabular}

KEYWORDS $\quad$ cross-border price, postal market, PES Index, ordinary least square

ABSTRACT The aim of the article is to analyze the impact of selected variables on the difference in cross-border price postal parcels weighing up to $2 \mathrm{~kg}$ offered by twenty-eight designated postal operators in the European Union countries in 2015 based on 756 collected observations. The study used data from Eurostat, the Universal Postal Union and the financial statements of designated postal operators. The base were nineteen indicators verifying the hypotheses about impact of selected groups of variables on the cross-border price. Moreover the analysis has been extended of electronic postal services indicators provided by designated postal operators, as defined by the Universal Postal Union, for selected countries. The results of the analysis confirm the complexity of the factors that affect the cross-border prices used by operators.

\section{Introduction}

The European Commission (2012) published a green paper on cross-border parcel delivery as a boost to development of e-commerce in the European Union. The purpose of the green paper was to create a single market for delivery services in response to the increasing share of online shopping, especially cross-border, that would contribute to the improvement of this market segment in European countries and would bring benefits of 
economic growth and job creation. Ensuring affordable and good quality cross-border parcel delivery services is also documented in another European Commission publication - A Digital Single Market Strategy for Europe (2015). European Commission conclude that cross-border delivery services can increase consumer confidence in crossborder online sales, because the lack of regulation in this area leads to a lack of transparency and interoperability between different entities dealing with cross-border consignments and excessive costs of small postal mail.

The one of the most important restrictions in cross-border trade is the geographical distance between countries, however this variable can be replaced in the research by a cross-border price (Gomez-Herrera, Martens, Turlea, 2013). On the other hand, the high price of postal delivery services is one of the major barriers to the development of the e-commerce market in the European Union, both in sales and in purchase of products (Duch-Brown, Martens, 2015). Conducted in study for online stores in Western European countries, which were indicated that the choice of a cross-border priority delivery was positively correlated with the GDP per capita and the difference in time delivery between express and conventional services and negatively with the transport cost to the selected region and the difference in the price margin between the supply express and conventional delivery (Kim Dekker, Heij, 2016).

The development of cross-border trade is therefore dependent primarily on the postal delivery price. The results of the analysis identified several important factors influencing the difference in the price of cross-border parcels post, including: distance, country destination, tracking module, weight of a parcel and common border (Claes, Vergote, 2016).

The purpose of this article is to investigate the impact of selected variables on the price of a two-kilogram cross-border postal parcel, taking into account macroeconomic factors and financial data of public postal operators because, as point out, an appropriate policy on cross-border postal delivery requires adequate quality of statistics to forecast and assess the impact of their introduction (Marcus, Petropoulus, 2016).

\section{Litepature review}

Okholm et al. (2016) indicated four factors related to the economies of scale that affect the price of crossborder postal parcels: volumes delivered, population density in the destination area, value added delivery features of delivery services and interoperability of postal networks. In addition, the price of the postal package was depending on degree of preparation of the parcel by the e-retailer and the content of the parcel, and may also be affected by a number of other cost factors, for example with: the business model of the delivery operator, labour costs, geography and exogenous factors like oil prices, currency risks, and traffic congestion.

Claes and Vergote (2016) analyzed the variability of the difference in the price of cross-border postal parcels between 25 European Union countries (excluding Cyprus, Estonia and Luxembourg) offered by designated operators. The dependent variable was defined as the percentage in difference between the cross-border and the domestic postal parcel price. The study used a series of variables that were divided in seven categories: product characteristics, single zone pricing, country groups, market structure, distance and demography, scale and cost factors. Conducted analysis showed that the impact on the difference in the cross-border package price was due to factors such as the distance, the use of premium tariffs, geographical classification of the country and the weight of the postal package, while the fit of the model measured by the $\mathrm{R}^{2}$ factor was equal 0.422 . It should be noted that most of the independent variables used were dummy variables, which could have influenced on the results. 


\section{Methodology}

The analysis covered 756 observations on the cross-border price postal parcel weighing up to $2 \mathrm{~kg}$ from the price lists of 28 designated operators to other European Union countries.

The study based on the analyzed literature adopted following form of estimated model using Ordinary Least Squares regression (OLS):

$$
\text { price_c } c_{i}=\alpha+\beta_{i} \times X_{i}+\varepsilon_{i} \text {, }
$$

where:

price_c $c_{i}$ - natural logarithm of cross-border price postal parcel weighing up to $2 \mathrm{~kg}$,

a $\quad$ - intercept,

$X_{i} \quad-$ matrix of explanatory variables,

$\varepsilon_{i} \quad-$ random component.

Based on the analysis of the significance of variables in the work Gomez-Herrera et al. (2013), Duch-Brown and Martens (2015), and Claes and Vergote (2016) 10 variables related to cross-border shipments and postal activity, 5 indicators relating to the economic environment and 4 variables related to the financial situation of postal operators were selected (Table 1).

Table 1. Select variables to the model

\begin{tabular}{ll}
\hline \multicolumn{1}{c}{ Variable } & Nescription \\
\hline $\begin{array}{l}\text { price_s } \\
\text { price_r }\end{array}$ & Natural logarithm of the price of a postal parcel weighing up to $2 \mathrm{~kg}$ in the sender's country \\
border & The dummy variable equal to one, if the countries have common border and zero otherwise \\
letter_price & Natural logarithm of the price of cross-border letter weighing up to $2 \mathrm{~kg}$ in the sender's country \\
distance & Natural logarithm of the distance expressed in kilometers between the capital of the country of the sender and the recipient \\
operator & The dummy variable equal to one, if the designated operator is the state company and zero otherwise \\
post_offices & Natural logarithm of the number of post offices in the sender's country in 2015 \\
priority & The dummy variable equal to one, if a postal parcel weighing up to $2 \mathrm{~kg}$ could be sent as a priority parcel and zero otherwise \\
priority_price & Natural logarithm of the price of a priority postal parcel weighing up to $2 \mathrm{~kg}$ in the sender's country \\
tariff & The dummy variable equal to one, if a designated operator applies a single tariff price to all European Union countries \\
& and zero otherwise \\
e2e & The dummy variable equal to one, if a postal parcel is delivered between countries in the euro area and zero otherwise \\
years_liberalization & Number of years since market liberalization \\
min_salary & The dummy variable equal to one, if in the sender's country has minimum salary and zero otherwise \\
gdp & Natural logarithm of the GDP per capita in the sender's country \\
zone & The dummy variable equal to one, if sender's country belongs to the euro area and zero otherwise \\
net_revenue & Natural logarithm of net revenues from sales of an operator designated in 2015 \\
net_revenue_3 & The dummy variable equal to one, if net revenues from sales decreased in the period 2013-2015 and zero otherwise \\
net_profit & The dummy variable equal to one, if in 2015 the company generated a net profit and zero otherwise \\
net_profit_3 & The dummy variable equal to one, if over the period 2013-2015 the negative net financial results were outweighed \\
pes ${ }^{1}$ & and zero otherwise \\
\hline
\end{tabular}

Source: own elaboration. 
The following hypotheses were tested in the article:

$\mathrm{H}_{1}$ : The use of variables related to cross-border shipments and postal activity will allow the model to be adjusted to 0.95 .

$\mathrm{H}_{2}$ : Enlarging the model with variables related to the economic environment will improve the fit of the original model.

$\mathrm{H}_{3}$ : Enlarging the model with financial variables will improve the fit of the original model.

$\mathrm{H}_{4}$ : Enlarging the model with PES indicator will improve the fit of the original model.

\section{Results}

Prior to the study, a Variance Inflation Factor test was performed on the occurrence of collinearity, which indicated that there was no collinearity in the model because no values were greater than 10 for the ten variables associated with cross-border shipments and postal activity and the mean value of the VIF test was 1.42.

In addition, the correlation matrix (Table 2) has shown a very strong, significant and positive relationship between cross-border price of postal parcel weighing up to $2 \mathrm{~kg}$ (price_c) and price of a priority postal parcel weighing up to $2 \mathrm{~kg}$ in the sender's country (priority_price), moderate (on strong boundary), significant and negative relationship between the distance (distance) and the having common border (border).

Table 2. Correlation matrix for the basic and significant variables used in the model

\begin{tabular}{|c|c|c|c|c|c|c|c|c|c|c|c|}
\hline Variable & 1 & 2 & 3 & 4 & 5 & 6 & 7 & 8 & 9 & 10 & 11 \\
\hline 1. border & 1.00 & & & & & & & & & & \\
\hline 2. distance & -0.59 & 1.00 & & & & & & & & & \\
\hline 3. letter_price & & 0.11 & 1.00 & & & & & & & & \\
\hline 4. operator & & & & 1.00 & & & & & & & \\
\hline 5. post_offices & 0.11 & -0.09 & 0.19 & -0.20 & 1.00 & & & & & & \\
\hline 6. price_c & -0.19 & 0.31 & 0.40 & 0.10 & 0.12 & 1.00 & & & & & \\
\hline 7. price_r & -0.19 & 0.31 & & & & 0.09 & 1.00 & & & & \\
\hline 8. price_s & & 0.06 & 0.20 & -0.17 & & 0.43 & & 1.00 & & & \\
\hline 9. priority & & & & & 0.14 & & & -0.26 & 1.00 & & \\
\hline 10. priority_price & -0.15 & 0.28 & 0.41 & 0.06 & 0.18 & 0.96 & 0.08 & 0.41 & 0.15 & 1.00 & \\
\hline 11. tariff & 0.06 & -0.08 & -0.23 & -0.06 & 0.08 & & & 0.34 & -0.26 & -0.07 & 1.00 \\
\hline
\end{tabular}

Source: own elaboration in RStudio.

Regression method performed with Ordinary Least Squares (OLS) for the ten basic variables (model 1) showed that seven variables were important in forecasting the cross-border price of the postal parcels (Table 3). Analysis for the model with constraints (model 2) showed that the seven variables identified in model 1 were significant. The value of the Wald test score of 0.91 , means that a restriction model should be chosen. The decrease of the cross-border price of a postal parcel was affected by the common boundary between countries, number of post offices in the sender's country and possibility of sending a postal parcel as a priority parcel. In turn, increase of postal letter price, distance, price of priority parcel and sending parcels by the state-owned operator has increased the value of the dependent variable. However, the value of the R-squared factor at $94.2 \%$ means that the first hypothesis should be rejected. 
Tahle 3. Regression results for each model

\begin{tabular}{|c|c|c|c|c|c|c|}
\hline Model & (1) & (2) & (3) & (4) & (5) & (6) \\
\hline price_s & $\begin{array}{l}-0.003 \\
(0.007) \\
\end{array}$ & & & & & \\
\hline price_r & $\begin{array}{c}0.000 \\
(0.009)\end{array}$ & & & & & \\
\hline border & $\begin{array}{c}-0.038^{* * *} \\
(0.014) \\
\end{array}$ & $\begin{array}{c}-0.038^{* * *} \\
(0.015)\end{array}$ & $\begin{array}{c}-0.031^{* *} \\
(0.014)\end{array}$ & $\begin{array}{c}-0.040^{* * *} \\
(0.014)\end{array}$ & $\begin{array}{l}-0.029 \\
(0.018)\end{array}$ & $\begin{array}{c}-0.041^{* * *} \\
(0.011) \\
\end{array}$ \\
\hline letter_price & $\begin{array}{l}0.024^{* *} \\
(0.010)\end{array}$ & $\begin{array}{c}0.025^{* * *} \\
(0.010)\end{array}$ & $\begin{array}{l}-0.001 \\
(0.010)\end{array}$ & $\begin{array}{l}0.019^{*} \\
(0.010)\end{array}$ & $\begin{array}{c}0.197^{* * *} \\
(0.023)\end{array}$ & \\
\hline distance & $\begin{array}{l}0.012^{*} \\
(0.007)\end{array}$ & $\begin{array}{l}0.012^{*} \\
(0.006)\end{array}$ & $\begin{array}{l}0.014^{* *} \\
(0.006)\end{array}$ & $\begin{array}{c}0.004 \\
(0.006)\end{array}$ & $\begin{array}{c}0.011 \\
(0.009)\end{array}$ & \\
\hline operator & $\begin{array}{c}0.058^{* * *} \\
(0.014)\end{array}$ & $\begin{array}{c}0.060^{* * *} \\
(0.013)\end{array}$ & $\begin{array}{c}0.046^{* * *} \\
(0.015)\end{array}$ & $\begin{array}{l}0.037^{* *} \\
(0.015)\end{array}$ & $\begin{array}{c}0.080^{* * *} \\
(0.017)\end{array}$ & $\begin{array}{l}0.042^{* * *} \\
(0.012)\end{array}$ \\
\hline post_offices & $\begin{array}{c}-0.006^{* *} \\
(0.003)\end{array}$ & $\begin{array}{c}-0.006^{* *} \\
(0.003)\end{array}$ & $\begin{array}{c}-0.008^{* * *} \\
(0.003)\end{array}$ & $\begin{array}{c}0.007 \\
(0.004)\end{array}$ & $\begin{array}{c}-0.035^{\star * *} \\
(0.005)\end{array}$ & $\begin{array}{c}0.030^{* * *} \\
(0.006)\end{array}$ \\
\hline priority & $\begin{array}{c}-0.118^{* * *} \\
(0.007)\end{array}$ & $\begin{array}{c}-0.116^{* * *} \\
(0.007)\end{array}$ & $\begin{array}{c}-0.130^{* * *} \\
(0.007)\end{array}$ & $\begin{array}{c}-0.134^{* * *} \\
(0.009)\end{array}$ & $\begin{array}{c}-0.140^{* * *} \\
(0.013)\end{array}$ & $\begin{array}{c}-0.135^{* * *} \\
(0.008)\end{array}$ \\
\hline priority_price & $\begin{array}{c}0.930^{* * *} \\
(0.011)\end{array}$ & $\begin{array}{c}0.927^{* \star *} \\
(0.010)\end{array}$ & $\begin{array}{c}0.932^{* * *} \\
(0.011)\end{array}$ & $\begin{array}{c}0.936^{* \star *} \\
(0.011)\end{array}$ & $\begin{array}{c}0.854^{* \star *} \\
(0.020)\end{array}$ & $\begin{array}{c}0.921^{\text {***}} \\
(0.009)\end{array}$ \\
\hline tariff & $\begin{array}{l}-0.002 \\
(0.008) \\
\end{array}$ & & & & & \\
\hline $\mathrm{e} 2 \mathrm{e}$ & & & $\begin{array}{c}0.001 \\
(0.008)\end{array}$ & & & \\
\hline years_liberalization & & & $\begin{array}{c}0.004^{* * *} \\
(0.001)\end{array}$ & & & $\begin{array}{c}0.006^{* * *} \\
(0.001)\end{array}$ \\
\hline min_salary & & & $\begin{array}{l}-0.007 \\
(0.010)\end{array}$ & & & \\
\hline gdp & & & $\begin{array}{c}-0.035^{\star \star *} \\
(0.008)\end{array}$ & & & $\begin{array}{c}0.030^{* * *} \\
(0.011)\end{array}$ \\
\hline zone & & & $\begin{array}{c}-0.017^{*} \\
(0.010)\end{array}$ & & & $\begin{array}{c}-0.016^{\star *} \\
(0.008)\end{array}$ \\
\hline net_revenue & & & & $\begin{array}{c}-0.014^{* * *} \\
(0.003)\end{array}$ & & $\begin{array}{c}-0.036^{* * *} \\
(0.005)\end{array}$ \\
\hline net_revenue_3 & & & & $\begin{array}{c}0.006 \\
(0.009)\end{array}$ & & \\
\hline net_profit & & & & $\begin{array}{c}-0.071^{* * *} \\
(0.020)\end{array}$ & & $\begin{array}{c}-0.111^{* * *} \\
(0.018) \\
\end{array}$ \\
\hline net_profit_3 & & & & $\begin{array}{c}-0.057^{* *} \\
(0.022)\end{array}$ & & \\
\hline pes & & & & & $\begin{array}{c}0.015 \\
(0.035)\end{array}$ & \\
\hline Intercept & $\begin{array}{c}0.059 \\
(0.057)\end{array}$ & $\begin{array}{c}0.056 \\
(0.054)\end{array}$ & $\begin{array}{c}0.473^{* * *} \\
(0.102)\end{array}$ & $\begin{array}{c}0.190^{* * *} \\
(0.061)\end{array}$ & $\begin{array}{c}0.063 \\
(0.082)\end{array}$ & $\begin{array}{c}0.003 \\
(0.122)\end{array}$ \\
\hline No. of obs. & 756 & 756 & 756 & 756 & 405 & 756 \\
\hline $\mathrm{R}^{2}$ & $94.2 \%$ & $94.2 \%$ & $94.6 \%$ & $94.5 \%$ & $92.3 \%$ & $95.1 \%$ \\
\hline
\end{tabular}

${ }^{* * *} p$-value $<0.01,{ }^{* *} p$-value $<0.05,{ }^{*} p$-value $<0.10$

Source: own elaboration in RStudio.

Expanding the model with variables related to the economic environment (model 3) has increased the fit of the model, which means that there is no reason to reject the second hypothesis. Three of the five variables turned out 
to be significant, with the number of years in since market liberalization positively affecting the cross-border price, while the size of GDP per capita and delivered parcel in the euro zone were negatively correlated.

Also expanding the model with financial variables (model 4) increased the fit of the model which means that there is no reason to reject the third hypothesis. Of the four variables, only a decrease in net revenue from sales over a three year period was irrelevant, but statistically positive, while the growth of the net revenue from sales, net income in 2015 and an outweighed the negative net financial results in the period 2013-2015 affected to increase the cross-border price.

Inclusion in the model of electronic postal services indicator (model 5) reduced the number of observations to 405 , because values were only available to 15 European Union countries. The PES indicator was statistically insignificant, and its inclusion reduced the fit of the model, so a fourth hypothesis should be rejected.

Analysis using all variables, and then limiting it to only relevant indicators (model 6) showed that the crossborder price was affected by ten variables. The size of the dependent variable was reduced by the dispatch of the consignment to the country with a common border - by $4.1 \%$, the possibility a giving postal parcel as a priority parcel - by $13.5 \%$, membership in the sender's country in euro zone - by $1.6 \%$, increased in net revenues of sales and achieved a net profit in 2015 - by $11.1 \%$. On the other hand, the increase in cross-border price was influenced by the ownership form of the operator, increase number of post offices - by $3.0 \%$, increase priority price of the postal package, number of years since market liberalization and increase GDP - by $3.0 \%$.

\section{Conclusions}

Okholm et al. (2016) have identified six factors affecting the development of cross-border e-commerce: experience/trust delivery, regulation as a driver, geographic/cultural drivers, technological drivers, operational drivers and price/cost drivers. The last factor associated with exchange rate fluctuations and the costs of dealing in other currencies and delivery prices charged by e-retailers may influence consumers' willingness to shop online.

The analysis showed that the impact on the cross-border price of postal parcels weighing up to two kilograms has many factors related to the activities of designated postal operators, but also its financial and economic environment. Sending a parcels to a country with a common border, the possibility of giving postal parcel as a priority parcel, membership in the sender's country in euro zone, increase in net revenues of sales and achieving a net profit in 2015 have contributed to a reduction of the cross-border price. On the other hand, the ownership operator form, the increase in the number of post offices, increase in priority price of the postal package, number of years since market liberalization and increase of GDP influenced in the growth of the dependent variable.

Identifying the factors affecting the cross-border price may help to increase the importance of e-commerce, however does not have to affect the decline in prices of products offered through online channels. In addition, the increased importance of cross-border e-commerce should be reflected in developing appropriate measures to support its development, which should contribute to job creation and stimulate economic growth (Duch-Brown, Grzybowski, Romahn, Verboven, 2017).

\section{Acknowledgments}

PES (Postal Electronic Services Index) - indicators of electronic postal services, as defined by Universal Postal Union (UPU). 


\section{References}

Claes, A., Vergote, W. (2016). Econometric study on parcel list prices. Retrieved from: http://ec.europa.eu/DocsRoom/documents/14647 (13.09.2017).

Duch-Brown, N., Martens, B. (2015). Firm barriers to cross-border e-commerce in the EU Digital Single Market. Retrieved from: https:// ec.europa.eu/jrc/sites/jrcsh/files/JRC96872.pdf (13.09.2017).

Duch-Brown, N., Grzybowski, L., Romahn, A., Verboven, F. (2017). The impact of online sales on consumers and firms. Evidence from consumer electronics. International Journal of Industrial Organization, 52, 30-62. DOI: http://dx.doi.org/10.1016/j. ijindorg.2017.01.009.

European Commission (2012). Green paper an integrated parcel delivery market for the growth of e-commerce in the EU. Retrieved from: http://ec.europa.eu/internal_market/consultations/docs/2012/parcel-delivery/121129_green-paper-parcel-delivery_en.pdf (13.09.2017).

European Commission (2015). A Digital Single Market Strategy for Europe. Retrieved from: http://eur-lex.europa.eu/legal-content/EN/ TXT/PDF/?uri=CELEX:52015DC0192\&from=EN (13.09.2017).

Gomez-Herrera, E., Martens, B., Turlea, G. (2013). The drivers and impediments for cross-border e-commerce in the EU. Information Economics and Policy, 28, 83-96. DOI: http://dx.doi.org/10.1016/j.infoecopol.2014.05.002.

Kim, T., Dekker, R., Heij, C. (2016). The value of express delivery services for cross-border e-commerce in European Union markets. Retrieved from: https://repub.eur.nl/pub/79921/El2016-12.pdf (13.09.2017).

Marcus, J.S., Petropoulos, G. (2017). E-commerce in Europe: Parcel delivery prices in a digital single market. In: The Changing Postal and Delivery Sector (pp. 139-159). Springer International Publishing. DOI: http://dx.doi.org/10.1007/978-3-319-46046-8_10.

Okholm, H., Boivie, A., Wahl, J., Jensen, K., Nygard, A., Basalisco, B. (2016). Principles of e-commerce delivery prices. Retrieved from: www.posteurop.org/NeoDownload?docld=456601 (13.09.2017).

Cite this apticle aS: Sylwestrzak, M., Stolarczyk, A. (2018). Impact of selected factors on the cross-border price of postal parcels in the European Union. European Journal of Service Management, 2 (26), 243-249. DOI: 10.18276/ejsm.2018.26-30. 